\title{
PELESTARIAN BAHAN PUSTAKA PASCA BANJIR BANDANG DI DINAS PERPUSTAKAAN DAN KEARSIPAN DAERAH KABUPATEN JENEPONTO
}

Saenal Abidin ${ }^{1}$, Muhammad Khudri Syam² \& Sitti Husaebah Pattah ${ }^{3}$

\author{
1,3Dosen Jurusan Ilmu Perpustakaan, Universitas Islam Negeri Alauddin Makassar \\ ${ }^{2}$ Mahasiswa Program S1 Jurusan Ilmu Perpustakaan UIN Alauddin Library, Universitas Islam Negeri \\ Alauddin Makassar \\ Correspondence email: $\underline{\text { saenal.abidin@uin-alauddin.ac.id }}$
}

\begin{abstract}
This research discusses "Preservation of Library Materials After Flash Floods in the Library and Archival Office of Jeneponto Regency". The purpose of the research is (1) To find out the efforts and forms of preservation of library materials conducted in the Library and Archival Office of Jeneponto Regency, (2) To find out the process of preservation of library materials after flash floods in the Library and Archival Office of Jeneponto Regency, (3) To find out the obstacles faced in the post-flash flood preservation process in the Library and Archival Office of Jeneponto Regency.

The type of research used is descriptive research with a qualitative approach. The data sources in this study are primary data and secondary data, data collection techniques through observation, interviews and documentation. Data analysis techniques in the form of data reduction, presentation of data and drawing conclusions to obtain the final result.

From the results of research and discussion it is known that Business and form of preservation of library materials after flash floods in the Library and Archival Office of Jeneponto Regency are (1) trying to save library materials that have been submerged in water and mud through the preservation of library materials in the form of preservation. (2) The process of preservation of library materials after flash floods in the Library and Archival Office of Jeneponto Regency, in addition to saving books, also to save the information contained in it and the process of preservation of library materials has 4 stages. (3) The obstacles faced are Dana, lack of staff knowledge about post-flood preservation activities and lack of equipment owned.
\end{abstract}

Keywords: Preservation, Preservation of library materials, Library materials, Flash floods.

\section{Abstrak}

Penelitian ini membahas "Pelestarian Bahan Pustaka Pasca Banjir Bandang di Dinas Perpustakaan dan Kearsipan Daerah Kabupaten Jeneponto". Tujuan penelitian yaitu (1) Untuk mengetahui usaha dan bentuk pelestarian bahan Pustaka, mengetahui proses pelestarian bahan pustaka pasca banjir bandang, dan untuk mengetahui kendala yang dihadapi dalam proses pelestarian pasca banjir bandang di Dinas Perpustakaan dan Kearsipan Daerah Kabupaten Jeneponto.

Jenis penelitian yang digunakan adalah penelitian deskriptif dengan pendekatan kualitatif. Sumber data dalam penelitian ini adalah data primer dan data sekunder, teknik pengumpulan data melalui observasi, wawancara dan dokumentasi. Teknik analisis data dalam bentuk reduksi data, penyajian data dan menarik kesimpulan untuk memperoleh hasil akhir.

Dari hasil penelitian dan pembahasan diketahui bahwa di Dinas Perpustakaan dan Kearsipan Daerah Kabupaten Jeneponto (1) Berusaha untuk menyelamatkan bahan pustaka yang telah terendam air dan lumpur melalui pelestarian bahan pustaka dalam bentuk preservasi. (2) selain untuk menyelamatkan buku, juga untuk menyelamatkan informasi yang terkandung di dalamnya serta proses pelestarian bahan pustaka ini memiliki 4 tahapan. (3) Kendala-kendala yang dihadapi yaitu Dana, Minimnya pengetahuan staf tentang kegiatan pelestarian pasca banjir dan kurangnya peralatan yang dimiliki.

Kata Kunci: Preservasi, Pelestarian bahan pustaka, Bahan pustaka, Banjir bandang. 


\section{A. Pendahuluan}

Salah satu yang menjadi bagian terpenting dalam perpustakaan adalah bahan pustaka. Hampir semua perpustakaan yang ada saat ini masih memiliki dan memanfaatkan bahan pustaka yang berbahan kertas, yang dimana bahan ini cenderung mudah untuk mengalami kerusakan baik itu robek, basah atau juga terkena noda dan dimakan rayap. Kerusakan ini jelas lambat laun akan terjadi, tergantung pada kualitas kertas dan juga iklim disuatu daerah, inilah mengapa koleksi perlu untuk dilestarikan. International Federation of Librarians Association (IFLA), yang memiliki prinsip berkaitan dengan pelestarian bahan perpustakaan, antara lain disebutkan bahwa perpustakaan nasional disetiap negara wajib menyelamatkan dan melestarikan satu eksemplar terbitan negaranya yang memiliki arti penting secara nasional. Pelestarian bahan pustaka sendiri tentu tidak hanya dilakukan untuk menyelamatkan fisiknya semata tetapi juga untuk melestarikan informasi yang terkandung di dalamnya.

Kegiatan pelestarian bertujuan agar usia pakai dari bahan pustaka dapat lebih lama serta pemustaka yang memanfaatkannya juga akan semakin banyak. Menurut Darmono (2001:70) pelestarian dan perawatan bahan pustaka di perpustakaan adalah hal yang perlu untuk mendapatkan perhatian. Tidak semua jenis perpustakaan harus melakukan pelestarian koleksi yang dimiliki, tetapi perawatan bahan pustaka wajib untuk semua jenis perpustakaan. Perawatan bahan pustaka menjadi wajib dilakukan sebab untuk menjamin koleksi yang dimiliki perpustakaan agar selalu siap untuk digunakan oleh pemustaka setiap saat.

Ada beragam hal yang menjadi pengaruh dari rusaknya bahan pustaka, baik dari ulah tangan manusia atau juga berasal dari alam. Indonesia adalah salah satu Negara yang rawan akan terjadinya bencana alam, sebut saja gempa bumi, banjir, longsor dan tsunami. Dari bencana alam ini akan timbul kerusakan dimana-mana baik secara material maupun juga non material.

Selama satu abad terakhir, sebuah riset yang dilakukan oleh Centre for Research on the Epidemiology of Disasters (CRED) menunjukkan, bahwa di Indonesia telah terjadi bencana alam besar sebanyak $343 \mathrm{kali}$. Secara keseluruhan, bencana tersebut telah menelan korban jiwa sebanyak 236.543 orang dan menyentuh 2.639 .025 penduduk. Daerah Indonesia beresiko terjadi bencana alam, dan telah menjadi bagian dari sejarah serta menjadi isu aktual. Salah satu penyebabnya karena wilayah Indonesia dilalui oleh dua jalur gunung berapi dunia, sirkum pasifik (Pacific ring of fire) dan sirkum Mediterania yang melintasi wilayah Pulau Sumatera, Jawa, Nusa Tenggara, hingga Sulawesi Utara (Murdiyanto 2015: 438). 
Bencana alam yang pernah terjadi di Indonesia dan berdampak besar adalah tsunami di Aceh tahun 2004 silam. Gempa tektonik yang terjadi di lepas pantai Barat Aceh pada 26 desember 2004 dan gelombang tsunami mematikan yang meluluhlantakkan hampir seluruh wilayah pesisir Provinsi Nanggroe Aceh Darussalam dan sebagian wilayah Sumatra Utara. Korban jiwa sendiri mencapai kurang lebih 237.448 jiwa sementara secara keseluruhan diperkirakan mencapai tak kurang dari 300.000 jiwa (Iwan 2005: 18). Pada tanggal 22 Januari 2019 yang lalu, telah terjadi bencana alam berupa banjir bandang di beberapa kabupaten yang ada di Sulawesi Selatan. Salah sataunya adalah Kabupaten Jeneponto yang mengakibatkan banyak warga terpaksa harus mengungsi. Bukan hanya itu, banjir bandang juga berdampak langsung pada kantor-kantor kedinasan dan fasilitas umum yang ada. Memang jika ditinjau lebih jauh Jeneponto sendiri sudah seringkali mengalami banjir, hampir setiap musim penghujan tiba beberapa daerah menjadi langganan banjir. Tetapi, banjir bandang kali ini tercatat sebagai banjir yang paling parah yang pernah terjadi di Kabupaten Jeneponto.

Kantor Dinas Perpustakaan dan Kearsipan Kabupaten Jeneponto adalah salah satu yang terdampak langsung banjir bandang yang terjadi. Ribuan eksemplar buku dan arsip menjadi rusak diakibatkan terendam air dan lumpur, juga tidak sedikit yang hanyut terbawa oleh air. Tidak hanyak koleksi monograf tetapi CD, Kaset dan server ikut terendam material lumpur pasca banjir bandang saat itu.

Apabila bencana alam menjadi sumber dari rusaknya bahan pustaka, tentu penanganannya akan berbeda jika kerusakan itu berasal dari ulah tangan manusia atau juga serangga. Sebab koleksi perpustakaan atau bahan pustaka sifatnya penting bagi suatu perpustakaan. Berdasarkan latar belakang ini, peneliti kemudian tertarik mengangkat judul "Pelestarian bahan pustaka pasca banjir bandang di Dinas Perpustakaan dan Kearsipan Daerah Kabupaten Jeneponto."

\section{B. Metodologi Penelitian}

Penelitian ini menggunakan jenis penelitian deskriptif dengan pendekatan kualitatif. Penelitian deskriptif adalah jenis penelitian yang bertujuan menjelaskan berdasarkan fakta yang ada serta bagaimana keadaannya. Menurut Moleong (2006: 50) Metode kualitatif adalah metode penelitian yang dimaksudkan agar dapat memahami fenomena tentang apa yang dialami subjek penelitian secara kualistik dengan mendeskripsikan dalam format. Kata-kata dalam bahasa pada suatu pertunjukan khusus dengan memanfaatkan berbagai metode alamiah.

Penulis berupaya untuk mendapatkan data sebagai informasi selengkap mungkin melalui hasil wawancara nantinya, atau juga dari sumber tertulis lain yang berkaitan untuk medukung data yang dibutuhkan oleh peneliti. Pendekatan kualitatif ini juga 
digunakan untuk mengungkapkan data-data deskriptif tentang pelestarian bahan pustaka pasca banjir bandang di dinas perpustakaan dan kearsipan Kabupaten Jeneponto.

\section{Hasil Penelitian dan Pembahasan}

\section{Usaha dan Bentuk Pelestarian Bahan Pustaka Yang Dilakukan Di Dinas Perpustakaan Dan Kearsipan Kabupaten Jeneponto}

a. Usaha Pelestarian Bahan Pustaka pasca banjir bandang di dinas perpustakaan dan kearsipan daerah kabupaten jeneponto

Kerusakan bahan pustaka yang diakibatkan oleh air sejatinya bukan sesuatu yang baru di Indonesia. Mengingat Indonesia merupakan sebuah Negara langganan bencana alam, dampak banjir yang terjadi adalah kerusakan, baik gedung maupun isinya. Apabila banjir terjadi maka sebuah lembaga perlu untuk setanggap mungkin dalam melakukan penanganan agar dapat mengetahui seberapa besar kerusakan akibat banjir ini.

Dalam dunia atau instansi perpustakaan bahan pustaka merupakan hal yang sangat penting adanya, sebab jika bahan pustaka seluruhnya habis oleh banjir maka sebuah perpustakaan sudah dapat dikatakan tidak memiliki arti apa-apa lagi. Mengenai pelestarian bahan pustaka pasca banjir bandang perlu untuk diketahui terlebih dahulu dulu separah apa kondisi yang dihadapi.

Usaha pelestarian bahan pustaka pasca bencana banjir yang dilakukan oleh Dinas Perpustakaan dan Kearsipan Kabupaten Jeneponto, bertujuan agar dapat lebih meminimalisir kerusakan sehingga koleksi yang terkena dampak banjir tetap dapat dimanfaatkan oleh pemustaka.

Usaha awal yang dilakukan di Dinas Perpustakaan dan Kearsipan, adalah mencoba untuk meminimalisir kontaminasi kerusakan dengan cara memisahkan koleksi yang masih bercampur lumpur, yang telah selesai dibersihkan dan yang sama sekali tidak mengalami kerusakan akibat banjir.

\section{b. Bentuk Pelestarian Bahan Pustaka pasca bajir bandang di dinas perpustakaan dan kearsipan daerah kabupaten Jeneponto}

Melakukan pelestarian bahan pustaka adalah sebuah kebutuhan yang sangat penting. Karena melalui pelestarian bahan pustaka akan lebih terjaga dan awet. Berikut adalah beberapa metode pelestarian yang dikenal:

1) Preservasi 
Preservasi adalah kegiatan yang perlu memiliki rencana serta tata kelola sehingga dapat dipastikan koleksi perpustakaan dapat terus dipakai dengan jangka waktu yang lama. Pada dasarnya preservasi itu upaya untuk mematikan agar semua bahan koleksi cetak maupun noncetak pada suatu perpustakaan bisa lebih lama dan tidak cepat rusak.

Preservasi merupakan sebuah langkah pelestarian untuk menjadi bentuk koleksi tetap utuh. Di dalam kebijakan preservasi koleksi perpustakaan atau bahan pustaka yang rusak tidak diperbaiki tetapi dalam preservasi koleksi yang rusak akan diusahakan tidak bertambah parah tingkat kerusakannya.

2) Konservasi

Konservasi merupakan pemeliharaan serta perlindungan sesuatu secara teratur untuk mencegah kerusakan dan kemusnahan dengan cara mengawetkan. Konservasi merupakan sebuah langkah yang diambil oleh pengelola perpustakaan untuk memperbaiki ulang koleksi perpustakaan atau bahan pustaka yang telah rusak.

Dinas Perpustakaan dan Kearsipan Daerah Kabupaten Jeneponto bersama dengan perwakilan dari Perpustakaan Nasional R.I melakukan preservasi terhadap bahan pustaka yang terdampak banjir tetapi masih layak untuk digunakan. Bentuk pelestarian bahan pustaka yang dilakukan adalah preservasi, dimana pustakawan dan staf perpustakaan yang dibantu oleh perwakilan Perpustakaan Nasional RI melakukan preservasi terhadap bahan pustaka yang telah rusak. Buku-buku yang masih layak untuk dilayangkan maka akan dilakukan pelestarian dengan cara preservasi dan apabila sudah tidak layak maka akan dilakukan pengadaan lagi.

Dalam usahanya melakukan pelestarian, Dinas Perpustakaan dan Kearsipan Daerah Kabupaten Jeneponto terlebih dahulu memilah koleksi agar dapat diketahui berapa banyak yang rusak dan yang masih bisa diselematkan. Untuk tehindar dari kerusakan dan memberikan perlakuan yang dirasa tepat terhadap bahan pustaka, terlebih dahulu perlu untuk dipahami apa saja yang menjadi faktor kerusakan. Beberapa faktor yang menjadi penyebab dari rusaknya bahan pustaka adalah sebagai berikut:

1) Faktor internal

Faktor internal adalah kerusakan yang bersal dari bahan pustaka itu sendiri, tingkat keasaman dari kertas yang dipakai itu dapat mempercepat kerusakan dari bahan pustaka. Kandungan senyawa kimia yang terdapat dalam kertas lambat laun akan terurai, terjadinya reaksi oksidasi serta hidrolisi akan menyebabkan lembaran kertas yang terdiri dari senyawa kimia itu akan terurai.

Di dalam kertas oksidasi terjadi sebab adanya oksigen dari udara menyebabkan sejumlah gugusan kerbonat dan karboksil serta akan dikuti dengan semakin 
memudarnya warna yang ada pada kertas. Reaksi yang terjadi karena adanya air (H2O) disebut Hidrolisis, hidrolisi akan mengakibatkan putusnya rantai polimer dan sesuloasa pada kertas sehingga dampaknya akan mengurangi kekuatan serat.

Maka dari itu asam merupakan kandungan zat yang berbahaya bagi kertas, terbentuknya asam didalam kertas terjadi dari berbagai macam sumber dan cara. Menurut Blasius Sudarsono (2006) faktor-faktor lain yang menyebabkan keruskan koleksi bahan pustaka adalah suhu, kualitas lingkungan, cahaya, hewan, insektisida dan jamur, penggunaan dan salah penanganan, bencana dalam dan musibah.

2) Faktor eskternal

Beberapa faktor eksternal atau faktor yang mempengaruhi kerusakan diluar dari bahan pustaka, antara lain:

a) Faktor lingkungan

Pengaruh lingkungan sekitar seringkali menjadi salah satu faktor yang dapat merusak suatu bahan pustaka yang ada. Faktor lingkungan antara lain:

a) Suhu dan kelembaban udara

b) Serangga dan binatang pengerat

c) Kutu buku

d) Kecoa

e) Rayap

f) Jamur

g) Cahaya

b) Faktor manusia

Manusia pada perpustakaan disebut sebagai pemustaka apabila mereka sebagai pengguna sedangkan untuk sebagai pengelola maka mereka akan disebut sebagai pustakawan. Dalam beberapa kasus manusia merupakan penjaga yang baik bagi bahan pustaka tetapi tidak jarang juga justru manusialah yang menjadi ancaman besar bagi bahan pustaka.

Kerusakan itu lahir akibat dari kelalaian yang dilakukan oleh manusia, baik dengan cara merobek lembar-lembar buku yang menurutnya penting untuk memenuhi tugas, menyoret-nyoret buku dan menumpahkan minuman atau makanan di bahan pustaka. Maka, tidak jarang perpustakaan melarang pemustaka untuk membawa makanan atau minuman masuk ke perpustakaan.

Kurangnya pemahaman pemustaka akan perlakuan terhadap bahan pustaka akan semakin berdampak buruk apabila tidak ada pencegahan 
yang dilakukan oleh pustakawan, yang dalam hal ini sebagai pengelola di perpustakaan.

Memang rasanya faktor kerusakan dari manusia ini adalah hal yang sulit untuk dibasmi, kesadaran yang dibutuhkan itu lahir dari dalam diri pemustakanya masing-masing. Setidaknya pustakawan harus tetap mengontrol para pemustakanya agar manusia tetap bisa menjadi sahabat baik bagi bahan pustaka.

c) Kerusakan akibat bencana alam

Bencana alam dapat memberikan dampak kerusakan yang cukup besar bagi perpustakaan baik itu kerusakan pada gedung dan juga koleksi yang ada di perpustakaan tentunya. Bencana alam adalah faktor kerusakan yang cukup serius bagi perpustakaan karena Indoneisa dikenal sebagai negara yang langganan bencana alam.

Deretan bencana alam ini sulit untuk diprediksi kapan akan terjadi dan seberapa parah dampaknya bagi perpustakaan, beberapa bencana alam yang seringkali terjadi Indonesia adalah sebagai berikut:

a) Banjir

b) Gempa bumi

c) Gunung meletus

d) Tsunami

Disamping itu bentuk pelestarian bahan pustaka yang dilakukan adalah preservasi dengan mencoba merekondisi bahan pustaka. Kerusakan bahan pustaka akibat dari bencana alam yang beragam tentu harus mendapatkan perawatan yang sesuai juga dan bisa jadi membutuhkan perawatan yang cukup serius. Membersihkannya dari sisa-sisa lumpur yang menempel hingga dapat dilayangkan kembali.

Dimana pustakawan dan staf perpustakaan yang dibantu oleh perwakilan Perpustakaan Nasional RI melakukan preservasi terhadap bahan pustaka yang telah rusak. Buku-buku yang masih layak untuk dilayangkan maka akan dilakukan pelestarian dengan cara preservasi dan apabila sudah tidak layak maka akan dilakukan pengadaan lagi.

B. Proses Pelestarian Bahan Pustaka Pasca Banjir Bandang di Dinas Perpustakaan dan Kearsipan Daerah Kabupaten Jeneponto

\section{Kondisi Dinas Perpustakaan dan Kearsipan Daerah Kabupaten Jeneponto}


Dinas Perpustakaan dan Kearsipan Daerah Kabupaten Jeneponto secara administrasi masuk ke dalam wilayah kecamatan Binamu. Berada di wilayah perkotaan sejatinya menjadi bagus bagi keberlangsungan perpustakaan, berhadapan langsung dengan salah satu kampus swasta membuat keberadaaan perpustakaan diharapkan mampu untuk menunjang kebutuhan informasi dan pendidikan pemustakanya. 22 Januari 2019 kabupaten Jeneponto diterjang banjir bandang, beberapa wilayah terendam banjir dan menimbulkan dampak yang cukup parah kala itu. Dinas Perpustakaan dan Kearsipan Daerah Kabupaten Jeneponto adalah salah satu yang merasakan dampaknya, perpustakaan terendam air setinggi 2 meter dan menyisakan lumpur setelah air mulai surut. Tingginya air serta endapan lumpur menjadi faktor dari rusaknya bahan pustaka yang ada di Dinas Perpustakaan dan Kearsipan Daerah Kabupaten Jeneponto. Peneliti yang saat itu ikut dalam proses pembersihan lingkungan perpustakaan mendapati lumpur yang telah tercampur oleh bahan pustaka yang masih belum diolah. Diperkirakan ada sebanyak 3000an koleksi yang saat itu hanyut dan terendam.

\section{Proses Pelestarian Bahan Pustaka Di Dinas Perpustakaan dan Kearsipan Daerah Kabupaten Jeneponto}

Dalam perpustakaan terdapat beragam bahan pustaka yang tersedia sebagai penunjang kebutuhan pemustaka, perpustakaan menyediakan koleksi yang terdiri dari berbagai jenis dan judul seperti pada Dinas Perpustakaan dan Kearsipan Daerah Kabupaten Jeneponto. Melalui jenis bahan pustaka inilah diharapkan mampu untuk menarik minat kunjung dari pemustaka. Maka, agar kondisi dari bahan pustaka tetap dapat digunakan perlu adanya pelestarian bahan pustaka.

Pelestarian bahan pustaka dilakukan untuk perbaikan dan penyelamatan bahan pustaka yang masih bisa untuk digunakan dan dimanfaatkan oleh pemustaka. Selain penyelamatan fisik (konteks), penyelamatan informasi (konten) yang ada di dalam suatu bahan pustaka juga penting untuk dilakukan. Sebagaimana telah dijelaskan sebelumnya bahwa faktor penyebab dari rusaknya bahan pustaka ada berdagam salah satunya adalah faktor alam. Dalam hal ini kasus banjir bandang yang telah menimpah kabupaten Jeneponto 2019 silam, memberikan dampak yang cukup parah bagi Dinas Perpustakaan dan Kearsipan Kabupaten Jeneponto. Pasalnya banyak bahan pustaka yang hanyut terbawa air dan rusak terendam lumpur, pelestarian pun hanya bisa dilakukan pada bahan pustaka yang tersisa dan masih layak.

Proses pelestarian bahan pustaka pasca banjir bandang ini memerlukan proses yang cukup lama dan berbeda dengan proses pelestarian yang dilakukan apabila faktor keruskannya berasal dari serangga atau ulah manusia. Proses pelestarian bahan 
pustaka pasca banjir bandang itu dilakukan bersama dengan pihak dari perpustakaan nasional. Proses pelestarian bahan pustaka secara keseluruhan bertujuan agar nilainilai informasi yang dalam bahan pustaka tetap terjaga dan dapat dimanfaatkan secara optimal. Lewat kegiatan pelestarian ini diharapkan agar umur pakai bahan pustaka dapat lebih lama.

Dalam pelestarian bahan pustaka pasca banjir bandang di Dinas Perpustakaan dan Kearsipan Daerah Kabupaten Jeneponto, memiliki prosesnya tersendiri. Berikut penjelasan proses pelestarian yang dilakukan pasca banjir bandang:

a. Pustakawan atau pengelola perpustakaan perlu untuk memilih dan memilah kembali mana koleksi yang masih dapat diselamatkan dan mana yang sudah tidak dapat lagi diselamatkan maupun untuk digunakan. Artinya bahan pustaka yang masih bisa untuk diselamatkan itu akan dibersihkan dari noda yang ada. Diperkiran jumlah koleksi yang rusak sebanyak 6.001 eksemplar dari total 7.013 eksemplar koleksi yang dimiliki.

b. Koleksi yang telah dipilih kemudian dibersihkan dari lumpur yang masih melekat baik pada sampul dan juga pada bagian lain. Dengan menggunakan alcohol 70\% untuk disemprotkan pada tiap halaman buku dan $96 \%$ digunakan untuk perendaman buku yang sudah sulit dibuka. Lumpur dan air membuat buku-buku menempel satu sama lain jadi apabila ingin dibersihkan, perlu perendaman terlebih dahulu agar lebih memudahkan.

c. Bahan pustaka yang telah selesai dibersihkan dari lumpur menggunakan alcohol kemudian dikeringkan dalam ruangan khusus yang telah dibuat dan dilengkapi dengan Dehumidifier (mesin penyedot lembab) selama kurang lebih 2-3 hari. Ruangan pengeringan terbuat dari plastik yang dibuat sedemikian rupa dan kedap udara dari luar, kemudian buku-buku akan di berdirikan dalam ruang tersebut selama kurang lebih 24 jam.

d. Diproses ini buku yang sudah dianggap benar-benar kering kondisinya akan renggang. Maka perlu dilakukan penekanan pada buku agar kembali rapat seperti awal mula buku tersebut. Penekanan atau penge-pressan ini dilakukan secara manual dengan alat khusus dan buatan. Alat buatan berasal dari dongkrak mobil yang dilapisi papan kayu kemudian diletakan beberapa tumpukan buku, proses ini memakan waktu kurang lebih 2-6 jam agar hasil yang diperoleh bisa maksimal.

Semua proses pelestarian bahan pustaka pasca banjir bandang ini dilakukan dengan bantuan dari Perpustakaan Nasional R.I dan Dinas Perpustakaan dan Kearsipan 
Provinsi Sulawesi Selatan selama satu minggu. Kemudian, dilanjutkan secara mandiri oleh pustakawan dan para staff Dinas Perpustakaan dan Kearsipan Kabupaten Jeneponto.

Dari hasil penelitian yang dilakukan oleh peneliti serta berdasarkan informasi yang didapatkan dari informan, dapat dilihat bahwa kondisi Dinas Perpustakaan dan Kearsipan Kabupaten Jeneponto pada saat terjadinya banjir bandang cukup memprihatinkan. Dengan gengan air dan endapan lumpur ini kemudian memperparah kondisi yang ada, belum lagi banyaknya bahan pusaka yang rusak dan bahkan hilang menambah beban tersendiri bagi Dinas Perpustakaan dan Kearsipan Daerah Kabupaten Jeneponto. Sedangkan untuk peroses pelestariannya sendiri ini memiliki setidaknya 4 tahapan utama, yakni:

1) Seleksi

2) Pembersihan

3) Pengeringan

4) Penge-press-an

Bantuan dari Dinas Perpustakaan dan Kearsipan Provinsi Sulawesi-Selatan serta Perpustakaan Nasional R.I dalam hal pelestarian bahan pustaka, menjadi salah satu kunci dari terlaksananya pelestarian bahan pustaka pasca banjir ini. Setidaknya pustakawan dan staf mendapatkan ilmu dan pengalaman baru.

Selain itu, bencana alam sebagai faktor kerusakan bahan pustaka tentu tidak bisa untuk diprediksi kapan dan bencana apa yang akan menimpa. Ini menjadikan pustakawan dan para pengelola harus siap sedia dalam menghadapi kondisi yang sewaktu-waktu dapat terjadi. Dinas Perpustakaan dan Kearsipan Kabupaten Jeneponto melakukan pelestarian bahan pustaka terhadap koleksi yang masih layak, dengan harapan bahwa informasi yang terdapat dalam bahan pustaka masih dapat untuk dimanfaatkan oleh pemustaka yang membutuhkannya.

Dalam hal ini pelestarian bahan pustaka yang dilakukan oleh Dinas Perpustakaan dan Kearsipan Daerah kabupaten Jeneponto sejalan dengan tujuan yang disampaikan oleh Sulistyo Basuki (1991:271) Tujuan pelestarian bahan pustaka adalah melestarikan kandungan informasi bahan pustaka dan arsip dengan alih bentuk menggunakan media lain atau melestarikan bentuk aslinya selengkap mungkin untuk dapat digunakan lebih maksimal.

Proses pelestarian bahan pustaka akibat banjir bandang memberi pengetahuan baru bagi pustakawan, staf dan pengelola perpustakaan. Teori-teori yang ada rasanya sudah cukup mampu memberikan gambaran bahwa betapa pentingnya pelestarian 
bahan pustaka sebagai upaya penyelamatan bahan pustaka secara fisik maupun secara kandungan informasi yang ada di dalamnya.

\section{Kendala Yang Dihadapi Dalam Proses Pelestarian Bahan Pustaka Pasca Banjir Bandang di Dinas Perpustakaan dan Kearsipan Kabupaten Jeneponto}

Setiap pekerjaan yang dilakukan pasti memiliki tingkat kemudahan dan kesulitannya masing-masing, maka disitu juga akan terdapat sebuah kendala yang harus dihadapi. Dalam pelestarian bahan pustaka juga memiliki kendalanya tersendiri, sebab pelestarian bahan pustaka bersifat penting dalam kegiatan pengolahan di perpustakaan. Umumnya pustakawan atau pengelola perpustakaan tidak pernah mendapatkan pendidikan formal tentang usaha pelestarian serta kendala lain macam dana, konsistensi, sumber daya manusia yang ada dan kendala-kendala lainnya. Pelaksanaan pelestarian bahan pustaka pasca banjir di Dinas Perpustakaan dan Kearsipan Daerah Kabupaten Jeneponto memiliki kendala dalam prosesnya.

1. Dana

Dalam kegiatan peletarian bahan pustaka pasca banjir bandang ini tentunya memerlukan dana yang tidak sedikit. Apalagi harus menyiapkan alat serta bahan untuk menunjang kegiatan pelestarian bahan pustaka pasca banjir bandang ini. Hal inilah yang menjadi salah satu penghambat dari kegiatan pelestarian yang akan dilakukan.

2. Kurangnya peralatan

Kurangnya peralatan yang dimiliki dalam pelestarian bahan pustaka pasca banjir bandang merupakan kendala utama juga. Peralatan tentu menjadi hal yang penting dalam proses pelestarian dan pencegahan yang diupayakan, sejatinya peralatan-peralatan pelestarian harus lebih dilengkapi lagi melalui pengadaan.

3. Minimnya pengetahuan staf tentang kegiatan pelestarian pasca banjir Tentu dalam melaksanakan kegiatan pelestarian memerlukan kemampuan serta pengetahuan, apabila staf minim pengetahuan mengenai perpustakaan khususnya pada kegiatan pelestarian ini bisa menjadi kendala sebab yang akan melakukan kegiatan tersebut adalah para staf, pustakawan dan pengelola perpustakaan.

Dapat dilihat bahwa ada beberapa kendala utama yang dihadapi oleh pustakawan dan pengelola perpustakaan di Dinas Perpustakaan dan Kearsipan Daerah Kabupaten Jeneponto dalam kegiatan pelestarian ini. Dalam konteks pekerjaan rasanya kedala dan masalah tentu saja akan selalu ada, sehingga apabila ditarik ke 
dalam proses peletarian bahan pustaka pasca banjir bandang ini tentu memiliki kendalanya tersendiri.

\section{Kesimpulan}

Berdasarkan hasil penelitian yang telah dilakukan, peneliti kemudian dapat mengambil kesimpulan mengenai pelestarian bahan pustaka pasca banjir bandang di Dinas Perpustakaan dan Kearsipan Daerah Kabupaten Jeneponto sebagai berikut:

1. Proses pelestarian bahan pustaka pasca banjir bandang di Dinas Perpustakaan dan Kearsipan Daerah Kabupaten Jeneponto, selain untuk menyelamatkan buku, juga untuk menyelamatkan informasi yang terkandung di dalamnya serta proses pelestarian bahan pustaka ini memiliki beberapa tahap, sampai akhirnya dapat untuk dilayangkan kembali.

2. Usaha dan bentuk pelestarian bahan pustaka pasca banjir bandang di Dinas Perpustakaan dan Kearsipan Daerah Kabupaten Jeneponto yaitu berusaha untuk menyelamakan bahan pustaka yang telah terendam air dan lumpur melalui pelestarian bahan pustaka dalam bentuk preservasi.

3. Kendala-kendala yang dihadapi selama pelestarian bahan pustaka pasca banjir bandang di Dinas Perpustakaan dan Kearsipan Daerah Kabupaten Jeneponto yaitu Dana, Minimnya pengetahuan staf tentang kegiatan pelestarian pasca banjir dan kurangnya peralatan yang dimiliki.

\section{Daftar Pustaka}

Darmono. (2001). Manajemen dan Tata Kerja Perpustakaan Sekolah. Jakarta: Gramedia Widiasarana Indonesia.

Murdiyanto dan Tri Gutomo. (2015). Bencana Alam Banjir dan Tanah Longsor dan Upaya Masyarakat Dalam Penanggulangan. PKS 14, (4) : hlm 437-452. (Diakses pada tanggal 15 maret 2021)

Iwan G. Tejakusuma. (2005). Analisis Pasca Bencana Tsunami Aceh. Alami 10, no. 2:1821. (Diakses pada tanggal 15 maret 2021).

Moleong, L. J. (2006). Metode Penelitian Kualitatif. Bandung.

Sudarsono, Blasius. (2006). Antologi Kepustakawanan Indonesia. Jakarta: Sagung Seto.

Sulistiyo-Basuki. (1991). Pengantar Ilmu Perpustakaan. Jakarta: Gramedia Pustaka Utama. 